\title{
STATUTORY INHIBITIONS UPON UNFAIR USE OF CORPORATE INFORMATION BY INSIDERS
}

\section{By Robert S. Rubin $\dagger$ and Myer Feldman +}

\section{INTRODUCTION}

It has been over twelve years since the enactment of Section 16 of the Securities Exchange Act of $1934^{1}$ which was designed to prevent the unfair use of inside information by corporate executives and principal stockholders. This was to be accomplished by taking the profit out of short-term insider securities trading, and by giving publicity to insider trading whether short or long term. The provisions of this section, together with Section 9, the anti-manipulation section of the Act, ${ }^{2}$ are among the most significant provisions contained in the federal securities laws. ${ }^{3}$ Prior to the enactment of Section I6 speculation on inside information was, probably one of the largest sources of income to management and other insiders. The invidious character of such trading is emphasized by the fact that the profit so obtained by the managers was not disclosed to the real owners of the corporation, to wit, the stockholders, and because it was often obtained at their expense.

The recent increase in the volume of trading and corporate financings has heightened public interest in the efficacy of the statutory provisions related to transactions by insiders. Accordingly, reexamination of Section 16 and cognate provisions of law in the light of experience over the past twelve years seems particularly appropriate.

$\dagger$ A. B., 1929, Columbia University ; LI. B., 193I, Columbia University; Associate Solicitor, Securities and Exchange Commission; member of the New York Bar.

$\$$ B. S. in Econ., I935, LL. B., I938, University of Pennsylvania; Gowen Memorial Fellow, University of Pennsylvania Law School, I938-9; Teaching Fellow, University of Pennsylvania Law School, I942; Attorney, Securities and Exchange Commission; member of the Pennsylvania Bar.

The views of the writers expressed herein are not necessarily to be construed as those of the Securities and Exchange Commission or any other member of its Staff.

I. 48 Stat. 84 (I9,33), r5 U. S. C. $\$ 77 p$ (I940).

2. $\$ 9,48$ STAT. 80 (r933), I5 U. S. C. \$77i (r940).

3. $\$ 17$ of the Public Utility Holding Company Act of 1935 serves a similar purpose with respect to securities of utility holding companies and their subsidiaries. $\S 30$ (f) of the Investment Company Act of I940 makes the provisions of $\S 16$ applicable to closed end investment trusts. \$ 10 (b) of the Securities Exchange Act of r934 and Rule X-10B-5 thereunder serves in a more limited way as a means for compelling disgorgement of profits made by insiders from trading with stockholders of their own companies, see infra p. 497 . See also $\$ 249$ of the Bankruptcy Act which deprives fiduciaries in corporate reorganizations from any compensation if they trade in the securities of a debtor during the pendency of the proceedings. Cf. In re Midland United Corporation, - F. (2d) - (C. C. A. 3d, I947), where it was held that this latter section includes trading in such securities by the wife of the fiduciary. 
Contrary to the general impression, apart from the utility field, the financial affairs of the sizable publicly owned companies are largely unregulated, leaving the absentee owner-stockholders largely unprotected except to the extent that the corporate managers voluntarily abide by their fiduciary obligations. A measure of protection is afforded absentee owners by the disclosure and reporting requirements of the Securities Act of $1933^{4}$ and the Securities Exchange Act of I934. However, in view of the wide area of unregulated activity on the part of corporate insiders and the general tendency of the courts to refrain from interference in corporate operations, increased importance is assignable to such provisions as Section I6 of the Securities Exchange Act, which supply minimum sanctions against the breaching of the seams of the fiduciary garments in which corporate management are clothed by law.

Extremely valuable tidbits of corporate information offer compelling temptations to misuse by those who have access to them. In addition, although various provisions of the Securities Exchange Act furnished the investor with information on which could be predicated an informed judgment of values, it was necessary that insiders be prevented from taking advantage of advance information concerning the disclosures so that the information received by the invester would not be made useless to him. Accordingly, Congress padlocked this particular corporate cupboard by taking the profit out of short-term speculative trading by insiders in the securities of their own companies. ${ }^{6}$ The basic purpose of this article is to examine and review the effect of this prescription.

The Securities Exchange Act of I934 had as its guiding light the overriding public interest in freeing the securities markets from all artificial influences so that they might reflect true values, and also to curb abuses by insiders who normally have access to confidential information not available to small stockholders and to the general public. In addition to removing the profit motive from short term insider trading, exchange practices were regulated, ${ }^{7}$ manipulative and deceptive devices were outlawed, and the extension of credit was supervised. ${ }^{2}$ The Act was broadly designed to stabilize the national

4. Securtties Acr of I933, §§ 5, 8, I0, 48 Stat. 77, 79, 81, I5 U. S. C. \$§ 77e, 77h, $77 \mathrm{j}(1940)$.

5. Securtites Exchange Act of I934, \$§ 12, 13, I4 and 16, 48 Stat. 892, 894, $\$ 96,15$ U. S. C. $\$ \$ 781,78 \mathrm{~m}, 78 \mathrm{n}, 78 \mathrm{p}$ (I940).

6 . It should be noted that $\$ 16$ liability is imposed only upon dealings in "equity securities" (defined in $\$ 3$ (a) (II)) of companies which have at least one class of such equity securities registered on a national securities exchange.

7. $\$ \$ 6,19,48$ STAT. 78,85 (I934), I5 U. S. C. $\$ \$ 77 f, 77 s$ (1940).

8. \$\$ 9, I0, I5, 48 Stat. 80, 8I, 84 (I934), I5 U. S. C. $\$ \$ 77 \mathrm{i}, 77 \mathrm{j}, 770$ (1940).

9. $\$ \$ 7,8,48$ Stat. 78,79 (I934), I5 U. S. C. $\$ \$ 77 g, 77 \mathrm{~h}$ (I940). 
economy against the shocks produced by a faulty investment system which had not adjusted itself to modern conditions. At the heart of the problem was the development of large corporations whose management was not as responsive to the ethical and legal sanctions present in earlier years when the companies were smaller, more localized and less widely owned. ${ }^{10}$

If officers, directors and controlling stockholders were permitted to purchase and sell stock in their enterprises and to profit from short swing increases or decreases in the price of the securities, there would be a strong temptation to withhold important information until - management had been afforded an adequate opportunity to profit thereby.

In an effort to do away with these abuses Section I 6 was enacted. In general, subsection (a) requires every person who is the beneficial owner of more than Io per cent of any class of equity security ${ }^{11}$ which is registered on a national securities exchange or who is a director or officer of the issuer of such security ${ }^{12}$ to file with the Commission and with the securities exchange a statement of ownership which indicates the amount of equity securities held and to report changes in that amount. In the only case in which the Commission has brought an injunctive action because of failure to comply with this reporting provision a consent decree was obtained. ${ }^{13}$

Subsection (b) provides in general, that all profits which accrue to such officer, director or beneficial owner of an issuer which has any equity security so registered on an exchange, from trading in any equity security of such issuer within a 6 months period shall inure to and be recoverable by the issuer, and authorizes suit in its behalf by any security holder upon failure or refusal of the issuer to institute the action. Specifically exempted are (I) transactions where the bene-

io. See Berle and Means, The Modern Corporation and Private Property (I932); T. N. E. C. Monograph No. 29, The Distribution of Ownership in the 200 Largest Non-Municipal Corporations (I940); T. N. E. C. Monograpi No. iI, Bureaucracy and Trusteeseif in Large Corporations (I940); Twentieth Century Fund, Inc., Big Business: Its Growth and Irs Place (1937).

II. "Equity Security" is defined by $\S 3$ (a) (II) of the Securities Exchange Act as follows:

"The term 'equity security' means any stock or similar security; or any security convertible, with or without consideration, into such a security, or carrying any warrant or right to subscribe to or purchase such a security; or any such warrant or right; or any other security which the Commission shall deem to be of similar nature and consider necessary or appropriate, by such rules and regulations as it may prescribe in the public interest or for the protection of investors, to treat as an equity security."

I2. $\S 17$ of the Public Utility Holding Company Act of I935 differs from $\S 16$ of the Securities Exchange Act of I934 in that its application is restricted to officers and directors of registered holding companies.

I3. Securities and Exchange Commission v. L. A. Young, Civil Action No. 4154 (E. D. Mich. I945). 
ficial owner ${ }^{14}$ was not such both at the time of purchase and the time of sale, (2) acquisitions of securities in good faith in connection with a debt previously contracted, and (3) such transactions as the Commission may, by rule or regulation, exempt as not comprehended within the purpose of the section.

Subsection (c), generally speaking, makes it unlawful for insiders either to sell their securities short or to engage in the practice of "selling against the box," a system whereby the owner of securities sells and then borrows securities from someone else to meet his commitment, hoping to purchase the securities later for delivery to his creditor at a lower price. ${ }^{15}$ This subsection may be enforced either by a criminal proceeding under Section 32 (a) of the Act ${ }^{16}$ where the violation is "wilful," or by an injunctive action by the Commission under Section $2 \mathrm{I}$ (e) of the Act, ${ }^{17}$ or by administrative action when a registered broker or dealer, or a member of a stock exchange has committed or participated in the violation. ${ }^{18}$

Subsection (d) gives the Commission the authority to exempt foreign and domestic arbitrage transactions from the purview of Section I6. However, the Commission has adopted a rule which has the effect of bringing such transactions by directors or officers, as distinguished from beneficial owners, within the provisions of Sections I6 (a) and (b). ${ }^{19}$

It is apparent that the provisions of Section I6 (b) impose upon insiders a liability beyond and in addition to that which exists under the common law. ${ }^{20}$ Apart from cases of misrepresentation, liability at common law was grounded upon the existence of a relationship between the buyer and the seller which conferred upon one of the parties special duties of disclosure. It did not adequately reach the subtleties of harm in connection with manipulation on the impersonal

I4. This exemption does not apply, it should be noted, to officers and directors.

15. This section is framed in terms of the failure to deliver the owner's security within a specified period.

I6. 48 STAT. 904 (1934), 15 U. S. C. \$78ff (a) (1940).

17. 48 StaT. 99 (I934), 15 U. S. C. \$78u (e) (1940).

I8. $\$ \S$ I5 (b), I9 (a) (3), 48 STAT. 895,898 (I934), I5 U. S. C. $\$ \$ 780$ (b), $78 \mathrm{~s}$ (a) (3) (I940).

19. Rule X-I6D-r.

20. Prior to the passage of the Securities Exchange Act of I934 there was conflict of opinion among the courts over the liability which an insider who traded in the securities of his corporation assumed. The majority of the state courts held that insiders were under no obligation so long as they did not actively mislead or falsify; the federal courts held that an obligation existed only when "special circumstances" were present which implied a duty of disclosure; and a small minority of the state courts held that an officer or director possessed a fiduciary responsibility toward the shareholders as well as toward the corporation, which was violated whenever he made a profit in transactions with them as a result of information which was acquired by reason of his position. See Yourd, Trading in Securities by Directors, Officers and Stockholders; Section I6 of the Securities Exchange Act (I939) 38 MICH. L. REv. I33, I39-I52. 
securities markets. The damages, if recoverable at common law, were payable to the plaintiff security holder who was defrauded. In contrast, Section I6 (b) requires any money award to be paid to the corporate treasury. It would seem that the common law remedy is still available to a security holder who can sustain the burden of proof required under the applicable state law. ${ }^{21}$

Perhaps the most important difference, however, lies in the rule of thumb adopted by the Act to discourage insider trading by requiring that all profits therefrom inure to the company. The statute does not require a finding that the trading was actually based upon secret undisclosed information or that an overall profit on all transactions was realized by the insider. Any profit realized from any single pair of non-exempt ${ }^{22}$ transactions which occur within any six months period inures to the corporation.

\section{Parties and Limitations}

The statute contemplates in the normal case an action instituted by the corporation. Since the defendant in such litigation is either a director, an officer, or an influential stockholder of the plaintiff, the defendant may be in a position to dominate the plaintiff corporation. This may result in the failure of the corporation to institute an action. In that event the provision of the statute permitting any stockholder to sue will then become operative. Moreover, in those instances in which the corporation does institute the action, even though it prosecutes diligently, there is danger that conflicting loyalties will affect the conduct of the litigation. To guard against such a result as noted, it has been held that any stockholder should have the right to intervene and represent an adversary interest when it appears that there is a community of interest between the parties to such litigation. ${ }^{23}$ Participation as amicus curiae is inadequate for it is essential that the stockholder be permitted to produce evidence at trial, cross examine witnesses, participate in examination before trial and at pre-trial conferences, file appeals from rulings of the trial court, and do all the other things that would ensure a full inquiry. Accordingly, it was held that intervention was warranted in accordance with the Federal Rules of Civil Procedure. ${ }^{24}$ Whether the corporation or the minority stock-

2I. $\$ 28$ (a) of the Act specifically preserves the legal and equitable rights which existed prior to the passage of the Act.

22. The burden of proof rests upon the person claiming the exemption. Cf. Securities and Exchange Commission v. Sunbeam Gold Mines Co., 95 F. (2d) 699 (C. C. A. 9th, I938); Edwards v. United States, Ir3 F. (2d) 286, 289 (C. C. A. Ioth, I940), rev'd on other grounds, 312 U. S. 473 (although sustained on this point, at p. 483).

23. Park \& Tilford, Inc. v. Schulte, - F. (2d) - (C. C. A. 2d, I947).

24. Ibid. Rule 24 (a) (2) provides that anyone shall be permitted to intervene whenever representation of the applicant's interest "may be inadequate." In a suit under $\$$ I6 (b), instituted by the corporation it should not be necessary to prove definitive in- 
holder institutes the action the court should jealously guard the character of the litigation by broadly construing the right of the minority security holder to participate. ${ }^{2 \mathrm{~J}}$

While there is a superficial similarity between Section I6 (b) suits and the ordinary stockholders' derivative actions, it is indicated clearly on the face of Section I6 (b) that it has a broader reach than such derivative suits in a number of important respects. Its fundamental purpose, moreover, is to make disgorging of insiders' profits almost automatic. Hence, those limitations that have been developed in respect to derivative suits, because many of them have been found to be unmeritorious, ought not to apply in the present context. Accordingly, in considering whether security holders who have become such after the transactions which form the basis for the action should be permitted to participate in or to initiate the proceedings, rules governing stockholders' derivative suits may not be helpful. The statute furnishes no explicit guide to the solution of this question but when the purpose of the Act, to deter insiders from short-term trading in their corporation's securities by causing any profits therefrom to inure to the corporation, is considered, it would seem that the right to prosecute $a \cdot 16$ (b) action should not be dependent upon the acquisition of the securities at a particular time.

In the ordinary stockholders' derivative action, there is a conflict of authority as to whether such actions may be commenced by stockholders who acquired their interest after the date when the cause of action arose. Rule 23 (b) of the Federal Rules of Civil Procedure requires the plaintiff to be a shareholder at the time of the transaction of which he complains or to have received his shares by operation of law. On the other hand, some state courts have reasoned that since the proceeds of a successful action would benefit both stockholders who acquired their interest prior to the transaction complained of and those who became stockholders after that transaction any stockholder should be permitted to sue to protect his interest. There are compelling reasons for adopting the latter point of view in Section I6 (b) litigation. ${ }^{26}$

In the first place, the security holder plaintiff ${ }^{27}$ in a Section I6 (b) action, in addition to seeking recovery for the benefit of all

adequacy. The dangers inherent in the situation call for the adoption of a rule of thumb which permits intervention whenever it appears there is a community of interest between the parties.

25. It has been the policy of the Commission to limit its appearance to that of amicus curiae and not to participate in any of the factual issues.

26. For a discussion of this problem in relation to shareholders' representative suits see Frey, Noteworthy Decisions in the Law of Private Corporations: I940-1945 (I946) 94 U. OF PA. L. Rev. 265.

27. Any security holder, regardless of whether he is the owner of an equity security or whether the security he owns is listed on an exchange may institute the action. 
present security holders as in the ordinary derivative suit, acts as an instrument of a statutory policy against short-term insider trading. As such, a defense addressed to the fact that he may have purchased his securities to qualify as a party to the action and is not aggrieved should be unavailable. A Section 16 (b) suit differs from a stockholder's derivative action in that it is founded upon a specific statute enacted to remedy an existing evil. Secondly, this statute grants the broad right to institute the action to "the owner of any security of the issuer" without any limitations upon the time when that security was acquired. To require the security holders to be such at some time prior to the trading activities in question would be incorporating a requirement into the Act not reassonably suggested by its words or purpose.

Before the action may be commenced by a person other than the corporation it is necessary that a request be made of the corporation and that it be given sixty days in which to comply with the request and in the ordinary case this opportunity should be accorded it. However, the situation may arise in which, if the cause of action is to be preserved, it will not be possible to wait the full sixty days. A statute of limitations of only two years is provided by Section I6 (b), and, generally, if the action is not instituted within that time it will be lost.

The short statute of limitations prescribed by Section I6 (b) presents a problem when an insider, either wilfully or negligently, fails to file the reports required by Section I6 (a) until more than two years after his trades occurred. A literal reading of the Act would seem to absolve him from liability for it provides that "no . . . suit shall be brought more than two years iffer the date such profit was realized." ${ }^{28}$ This language, however, must be read in the light of the purpose of Section I6 (b) and the decisions construing comparable federal statutes.

The Securities Exchange Act establishes three sanctions for enforcement of those provisions relating to the prohibition upon insider trading. (I) Section I6 (a) sets forth certain reporting requirements designed to provide publicity for such transactions. (2) Section I6 (b) provides for the recapture of any short-term profits at the suit of the corporation or a security holder acting in its behalf. (3) Section I6 (c) makes certain types of such transactions unlawful, so that civil remedies and criminal penalties may be invoked by the Commission. These three sanctions are integral parts of a statutory scheme designed to prevent any insider from taking advantage of facts unknown to the investors in the corporate enterprise. Thus, Section $I 6$ (a) is aimed

28. $\S 16$ (b), 48 STAT. 896 , I5 U. S. C. $\$ 78 p$ (I940). 
at providing the information which must form the basis for any action taken under the other subdivisions of Section I6. Failure to comply with I6 (a) will necessarily hamper the enforcement of I6 (b) and I6 (c). It appears, therefore, that if the full purpose of Congress is to be accomplished the limitations period prescribed in Section I6 (b) should not start with the date the profit is realized unless the disclosure required by Section $x 6$ (a) is made. ${ }^{29}$ Support for this view in the case of suit by a stockholder under Section I6. (b) may be derived from the recent decision of the United States Supreme Court in Holmberg $v$. Armbrecht. ${ }^{30}$ In the Holmberg case a derivative suit was instituted in New York in behalf of the Southern Minnesota Joint Stock Land Bank of Minneapolis to enforce a liability imposed upon shareholders of the bank by the Federal Farm Loan Act. Although the applicable state statutory period of limitations had elapsed since the cause of action arose, it was alleged that the action was not barred because the fraud of defendant in concealing his identity during that time had delayed the discovery of the cause of action. The suit was resisted on the ground that the Supreme Court decision in Guaranty Trust Co. v. York $^{31}$ required the New York statute of limitations to be applied. In holding the Guaranty Trust case inapplicable the Court said:

"This equitable doctrine is read into every federal statute of limitation. If the Federal Farm Loan Act had an explicit statute of limitation for bringing suit under $\$ I 6$, the time would not have begun to run until after petitioners had discovered, or had failed in reasonable diligence to discover, the alleged deception . . . which is the basis of this suit." 32

Under rules set forth in this decision, therefore, the federal equitable doctrine should be read into the explicit statute of limitations provided in Section $r 6$ (b) and the time would not begin to run until plaintiffs in a Section 16 (b) action have discovered or with reasonable diligence should have discovered the transactions which form the basis for the action. An insider who, by failing to file the reports required of him by Section I6 (a) or by other means deceives the corporation and its stockholders; may not set up his deception as a defense against a suit based upon one of the other subdivisions of Section $16 .^{33}$ Full application of the Holmberg decision seems appropriate, since the short statute of limitations would seem to have been adopted because it ap-

29. Cf. Bigelow v. R. K. O. Pictures, Inc., 327 U. S. 25 I (I946).

30. 327 U. S. 392 (I946).

3I. 326 U. S. 99 (I945).

32. Cited supra note 30 . wilful.

33. Nor would it appear material whether the failure to comply with the Act was 
peared that by virtue of Section i6 (a) there would be a prompt disclosure to all security holders of trading in the corporate stock.

\section{ENFORCEMENT}

\section{(a) Jurisdiction and Venue}

Actions filed pursuant to Section I6 (b) "may be instituted at law or in equity," under the terms of that Section, "in any court of competent jurisdiction." Without further examination of the statute it would seem that suit may be instituted in any court with jurisdiction over suits at law or equity for the recovery of monies. However, section 27, which sets forth the jurisdictional requirements for the Act as a whole, specifies that:

"The district courts of the United States, the Supreme Court of the District of Columbia, and the United States courts of any Territory or other place subject to the jurisdiction of the United States shall have exclusive jurisdiction of violations of this title or the rules and regulations thereunder, and of all suits in equity and actions at law brought to enforce any liability or duty created by this title or the rules and regulations thereunder. . ."34 (Emphasis supplied.)

Were it not for Section 27 the jurisdictional provision of Section I6 (b) would appear to give state courts the power to entertain I6 (b) actions. But Section 27 makes it clear that only federal courts may entertain such actions.

In the only decision upon this question the New York Court of Appeals held that a Section I6 (b) suit could not be maintained in the New York state courts because of the positive language of Section 27 conferring exclusive jurisdiction under the Act upon the federal courts. The phrase "any court of competent jurisdiction" in Section I6 (b), it was held, referred to courts in the federal system only. ${ }^{35}$ Moreover, the statute makes it clear that Section 27 applies to suits under Section $I 6$ (b), and is not limited to suits brought by the Commission, as has been contended. The express provisions of Section 27 refer to "all suits" to enforce any liability or duty created by the Act. ${ }^{36}$

Assuming, then, that only federal courts may entertain I6 (b) actions, it becomes pertinent to inquire which federal courts are "com-

34. 48 STAT. 902 (I934), I5 U. S. C. $\$ 78$ aa (I940)

35. American Distilling Co. v. Brown, 295 N. Y. 36 (I945).

36. Cf. Kardon 'v. National Gypsum Co., - F. Supp. - (E. D. Pa. 1946); FifthThird Union Trust Co. v. Block, Civil Action No. I507 (Unreported, S. D. Ohio 1946) ; Slavin v. Germantown Fire Ins. Co., Civil Action No. 6564 (Unreported, E. D. Pa. I946). 
petent" within the meaning of Section I6. . It is clearly stated that venue may be established where the defendant is found, where the defendant is an inhabitant, or where the defendant transacts business. ${ }^{37}$ It is not quite so clear whether the action may be instituted in the place where the exchange involved is located or where the transaction in question occurred.

The original drafts of the Act provided for venue in both civil and criminal proceedings in the district "wherein the exchange involved is operated," $3 s$ in addition to the language which survived in the Act in its final form. These additional words were dropped in the bill as reported out by both Committees without indication of any reason for doing so. It would seem that they were dropped as surplusage, for when Section 27 says "Any suit or action to enforce any liability or duty created by this title . . . may be brought in any such district . . ." it refers to the preceding sentence, which permits criminal proceedings to be instituted "in the district wherein any act or transaction constituting the violation occurred." Since the purchase and sales are the transactions which give rise to the I6 (b) liability the action may be instituted in any place where these purchases and sales take place. . Thus, the Act as finally passed includes, as an alternative venue, the place where the exchange involved is located, if the transaction creating the liability is executed thereon, or where the transactions in question occurred.

It should be noted that in using the phrase "such district" Section 27 refers back to "the district wherein any act or transaction constituting the violation occurred." One seeking to avoid suit in the place where the trading occurred would argue that the latter phrase refers only to acts made unlawful by the Securities Exchange Act. Only those acts, it would be contended, are "violations"; therefore, the phrase "such district" has reference only to suits instituted under sections of the Act which make actions "unlawful."

This argument is based upon the assumption that civil actions brought in "such district" must be based upon "violations" and that "violations" refer only to breaches of the criminal law. If the latter argument were adopted it would become necessary to prove certain acts criminal in character in order to sustain the venue in a civil suit. Thus, Section I8 (a) provides for civil actions for damages resulting from certain false and misleading statements and makes such statements actionable, whether or not also subject to the criminal sanctions

37. Query whether the defendant transacts business in the district where the purchase or sale of securities takes place. See Eastman Kodak Co. v. Southern Photo Materials Co., 273 U. S. 359 (I927).

38. Sen. 2693, 73d Cong., 2d Sess. (1934) ; H. R. 7852, 73d Cong., 2d Sess. (1934). 
of Section 32 (a) because "wilfully and knowingly" made. It would become necessary to prove the wilfulness of the false statement to avoid dismissal for improper venue. Thus, the venue would be dependent upon the proof of the criminal character of the act while the basic issue of civil liability would not require such proof. Congress can hardly have intended such a result.

It is likewise apparent from the context in which the words "such district" appears in the venue portion of Section 27 of the Act that the district referred to was intended to be an available forum for both suits to enjoin violations and suits to enforce liabilities. To the extent, therefore, that violations are not a prerequisite to civil liability, it could not have been intended that the acts which fix venue within a particular district must amount to a "violation" even in the civil sense.

Furthermore, although short-term trading by owners, directors, and officers in the securities of their corporation is not made a "violation" of the Securities Exchange Act of I934 in the sense of an act prohibited, Section I6 expressly embodies the strict statutory policy against such conduct on the part of corporate insiders. Thus, the statute provides that it is: "For the purpose of preventing the unfair use of information by [insiders]." Plainly, the statute seeks to put a stop to such trading, and enforces its policy by removing all opportunity to profit thereby. Accordingly, if it is necessary to have a "violation" as a basis for liability, it is probable that what was intended is the violation of the statutory policy against short term insider trading. ${ }^{39}$ This policy was expressed in the case of Smolowe $v$. Delendo Corp." as the establishment of "a standard so high as to prevent any conflict between the selfish interest of a fiduciary officer, director, or stockholder and the faithful performance of his duty." Short-term trading by insiders, the court said, was "within the general scope of the legislature's intended prohibition." 41

It is important to provide a wide choice of venue for 16 (b) actions in order that the shareholder may not be handicapped in his attempt to enforce the liability created by that section. Without venue in the place where the transaction occurred an insider might effectively insulate himself from liability by maintaining his residence and place of business in a state or foreign country distantly removed from the

39. In Baird v. Franklin, I4I F. (2d) 238 (C. C. A. 2d, 1944) suit was instituted against the New York Stock Exchange for its failure to take disciplinary action against a member under rules which it had adopted as required by $\$ 6$ (b) of the Securities Exchange Act. This failure was held (per Clark, J.) to be a "violation" of $\S 6(\mathrm{~b})$, although that section did not make anything "unlawful." In Goldstein v. Groesbeck, I42 F. (2d) 422 (C. C. A. 2d, 1944) the Circuit Court of Appeals for the Second Circuit defined "act or transaction constituting the violation" as "any breach of duty causing injury or loss to private persons." Id. at 425 .

40. I36 F. (2d) 23I, 239 (C. C. A. 2d, 1943).

4I. Id. at 237 . 
residence of the shareholders and the corporation. This would place a difficult burden upon the person instituting the action. Since in many cases it would be a shareholder, and not the corporation, which commenced the proceedings, the burden would usually have to be borne by a person unable to bear it from the financial and practical standpoint.

On the other hand, a holding which permitted suit to be instituted where the transactions took place would frequently result in permitting the venue to be laid where the exchange is located, and consequently within the general area in which many of the stockholders are resident or doing business. If the insider trades in any given place, he cannot with grace complain because he may be sued there. ${ }^{42}$

Service of process under the specific language of Section 27 does not have to be made in the district in which suit is begun. Service of process may be effected by the local marshal at the place where the insider is an inhabitant or is found. ${ }^{43}$

No court as yet has had presented to it the problem of venue when some, but not all, of the transactions which form the basis for the I6 (b) action take place within a particular district. It would be manifestly improper to divide the cause of action so that the suit is limited to the recovery of profits which result solely from the sales and purchases within that district. Nor would it be consonant with the intent of Congress to deprive a shareholder of the right to bring the action at the place where the transaction occurred because other transactions giving rise to a similar liability occurred elsewhere. The only way in which the intent of Congress to provide for a wide choice of venue could be accomplished is by construing the Act to mean that suit may be instituted wherever any transaction giving rise to the violation occurred and by permitting the joinder of causes of action arising in other districts in the interest of an efficient prosecution of the claim.

\section{(b) Attorneys' Fees}

Whether the action is instituted by the corporation or by the security holder the Act provides that the profits shall "inure to and be recoverable by the issuer." 44 The judgment secured, therefore, will be payable to the corporation. Thus, where it is necessary for the security holder to institute the action his gain will be limited to his

42. One of the tests for listing on an average is distribution within the vicinity of the exchange.

43. $\$ 27$ provides that "process . . . may be served in any other district of which the defendant is an inhabitant or wherever the defendant may be found." Similar language in the Securities Act of 1933 was construed in Cohen v. Saddlemire, 26 F. Supp. 27 (D. Mass. 1939).

44. § 16 (b), 48 STAT. 896 (1934), I5 U. S. C. \$78p (1940). 
pro rata interest in the corporation. In most instances this would be a trifling amount which would not even defray the cost of suit and counsel fees.

In recognition of this practical problem it would seem clearly desirable to encourage proper litigation by awarding the attorney for a successful plaintiff in a Section I6 (b) action reasonable counsel fees. ${ }^{4 \bar{J}}$

The whole problem of the enforcement of actions designed to prevent insiders from profiting from trading in securities of their own corporations is likely to meet the same objections which have been urged against the so-called "striker's suits." In the reward which is offered in the way of fees for the successful prosecution of such cases it is urged that litigation is encouraged upon the slightest pretext. The accusation that these derivative suits are therefore champertous has led many states to restrict the right of stockholders to bring such actions by imposing conditions regarding the financial responsibility of the real party plaintiff. ${ }^{46}$ Similar restrictions would be undesirable in Section $\mathrm{r} 6$ (b) actions, for the action is based upon a clear statutory right to the recovery which is designed to promote aggressive enforcement of the effort to curb short-term insider trading. Unlike the ordinary derivative stockholders' suits, the action under Section I6 (b) is not fraught with doubt as to whether a cause of action exists. Indeed, in most instances recovery is practically automatic, the basis of the liability appearing in the reports filed with the Commission by the defendant."

\section{(c) Discontinuance}

It may be that a Section I6 (b) suit is neither settled ${ }^{48}$ by the parties nor concluded by a judgment of the court. Instead, the litiga-

45. Smolowe v. Delendo Corp., r36 F. (2d) 23r, 24I (C. C. A. 2d, r943), cert. denied, 320 U. S. 75I (I943) commented on the award of counsel fees as follows:

"While the allowance here was quite substantial we are not disposed to interfere with the district court's well-considered determination."

This is to be compared with the rule applicable to allowances awarded in bankruptcy proceedings, where it is settled that the court must guard against "vicarious generosity" and be economical in its distributions. Levin v. Barker, I22 F. (2d) 969 (C. C. A. 8th, I94I) ; In re Standard Gas and Electric Co., 106 F. (2d) 215 (C. C. A. 3d, I939) ; Stark v. Woods Bros. Corp., rog F. (2d) 969 (C. C. A. Sth, I940). See also Park \& Tilford, Inc. v. Schulte, et al., No. 57,. Oct. Term, I946 (C. C. A. 2d, I947).

46. See, e. g., N. J. Rev. Stat. tit. I4:3-I5, Corp. Manual (1946) I3I6-I3I7; N. Y. Gen. CoRp. LaW \$ 6I-5, Corp. Manual (I946) I423; I2 Pa. Stat. ANn. (Purdon, I945) § I322, CoRp. MaNual (I946) I753; WIS. STAT. § I80.I3 (3), added by L. I945, c. 462, CoRP. MANUAL (I946) 2224 .

47. The statement of ownership required by $\S \mathrm{I} 6$ (a) does not provide for a disclosure of either the price paid for the security or the price for which the security was sold. However, an approximation can readily be ascertained by an examination of the range of prices on the day the transaction occurred.

48. Settlement of $\S I 6$ (b) litigation would seem to be governed by FED. Rutes Crv. Proc. Rule 23 (c). 
tion may be voluntarily discontinued by the party with control over it. Under the principles governing the right to intervene it would seem that any security holder who might have instituted the action originally should have the right to continue the action. ${ }^{48}$ Assuming, however, that application is not seasonably made to intervene, the suit should be permitted to be terminated.

Where a corporation dominated by an insider being sued has instituted the $16(\mathrm{~b})$ action there would be a temptation to utilize the device of discontinuance to avoid liability. Only by careful scrutiny of 16 (b) actions which are discontinued and by liberal grant of permission to reopen such proceedings can this danger be obviated. Even where a minority security holder has instituted the action, the terms of any discontinuance should be approved by the court. Nor does the practice of giving notice and opportunity to intervene to all security holders exhaust the jurisdiction of the court. Under its equitable powers it may, even though no qualified person offered to continue the litigation, require that any increment to a stockholder from sale of his securities which is connected with an agreement to thereby disqualify himself from continuing the action should inure to the corporation.

Under this doctrine the proceeds of the sale are divisible into two parts; that which represents the reasonable value of the securities, and that which represents the additional sum paid in order to secure a discontinuance of the action. For the latter amount the stockholder is accountable as a fiduciary. This rule does not prevent discontinuance of actions in the interest of a speedy termination of the litigation. Rather, it guarantees that a security holder, once having undertaken to guard the rights of his class by instituting or intervening in a I6 (b) action, will be held to the same level of accountability as a security holder acting in a representative capacity in other types of litigation. ${ }^{50}$

\section{Transactions and Profits Reached By the Act}

A share of stock is fungible, with exactly the same rights as any other share of the same class. Accordingly, delivery of a particular share of stock is not required under a purchase or sales contract, and the profit realized upon a particular sale or purchase is not necessarily attributable to the particular certificate delivered, even though it has been carefully segregated. For tax purposes a "first in first out" rule has been adopted under which it is presumed that the shares first I942).

49. See Golconda Petroleum Corp. v. Petrol Corp., 46 F. Supp. 23 (S. D. Cal.

50. See Young v. Higbee, 324 U. S. 204 (I945) ; Clarke v. Greenberg, - N. Y. - (I947). 
purchased are first sold. ${ }^{51}$ Although this method of determining the profit realized is consonant with the theory of the income taxing statute it would not accomplish the objectives of Section 16 (b), which seeks to prevent profits from insider trading.

If either the rule that the exact certificate purchased and sold determines the profit realized or the "first in first out" theory were adopted in Section I6 (b) situations, an easy method of evasion of the purposes of Section 16 would be at hand. Many insiders maintain a substantial block of their corporation's securities. By carefully transferring securities purchased more than six months before a sale or by relying upon the securities on hand to constitute the purchase which is to be matched against a subsequent sale, insiders could maintain their position while trading at will, without coming within Section I6 (b). Obviously, such trading would be a violation of the spirit and intent of Congress, and it would lead to the abuses which Section I6 (b) was designed to prevent.

Similarly, if an "average cost" theory, such as that applied by the tax laws to securities acquired simultaneously in reorganizations, were applied to Section I6 (b) trading, it would fall short of the Congressional purpose. As first proposed, Section I6 (b) made shortterm trading "unlawful." This was modified because it was felt that criminal sanctions were not necessary, except with respect to certain types of transactions such as short sales. However, the dominant purpose of the section remained to discourage all such trading. Only a rule which would admit of no short-term profits could accomplish this purpose.

The Court of Appeals for the Second Circuit, in the case of Smolowe v. Delendo Corp. ${ }^{52}$ enunciated such a rule. Under this rule, the profits are calculated in the following fashion: Listed in one column are all the purchases made during the period for which recovery of profits is sought. In another column is listed all of the sales during that period. Then the shares purchased at the lowest price are matched against an equal number of the shares sold at the highest price within six months of such purchase, and the profit computed. After that the next lowest price is matched against the next highest price and that profit is computed. Then, the same process is repeated until all the shares in the purchase column which may be matched against shares sold for higher prices in the sales column have been matched off. Where necessary to accurate computation it would seem proper to split a larger denomination or lot of shares in order to match off

5x. Internal Revenue Reg. III, \$29.22 (a)-8 (I943).

52. 136 F. (2d) 23 I (C. C. A. 2d, I943), cert. denied, 320 U. S. 75 I (1943). 
part of the lot against an equal amount on the other side. The gross recovery is the sum of the profits thus determined.

This method may result in a recovery by the corporation, even though the transactions as a whole result in a loss, for even if there is only one purchase at a price lower than a sale within six months, a realizable profit results. ${ }^{53}$ However, it is only by employing a test of profits such as this that the public interest of investors may be protected against actions by fiduciaries which are inconsistent with their trust. Speculative trading by insiders is made so unattractive that the practical consequence of the statute will be effectively to deter speculative trading on inside information.

The ascertainment of profit becomes more difficult when a security is acquired or disposed of by a method other than the simple purchase or sale. The broad definition of "security" in Section 3 (a) (IO) is sufficiently inclusive to encompass all of the ordinary devices by which ownership in a common enterprise is indicated. ${ }^{54}$ Warrants and the right to subscribe to securities are specifically mentioned, so that traffic in options or warrants would seem to clearly fall within the scope of Section I6 (b). Section 3 (a) (II) defines equity securities to include stock and any similar security, securities convertible into stock or carrying subscription warrants or rights to stock and such warrants or rights, and other securities treated as an equity security by the Commission's rules.

The Act defines "purchase" to "include any contract to buy, purchase, or otherwise acquire," 55 and the term "sale" is similarly defined to "include any contract to sell or otherwise dispose of." 56

Two recent cases have raised the question whether the acquisition of securities by reason of a conversion of one security into another is within the purview of Section I6 (b). The cases arose out of similar transactions and both held that the transactions were reached by the statute. In one, Kogan v. Schulte, ${ }^{57}$ the stockholder sued in behalf of the corporation to recover the profits and in the other, Park $\&$ Tilford $v$. Schulte, et al., ${ }^{58}$ the corporation sued in its own name,

53. In recognition of the high standard of conduct which a fiduciary must obey a similar rule is followed, which deprives protective committees, counsel and other fiduciaries in corporate reorganization proceedings of any fee or allowance when they have engaged in any practice which might involve a conflict between their personal interests and those of their cestuis, even where individual hardship occurs. In re Mountain States Power Co., II8 F. (2d) 405, 407 (C. C. A. 3d, I94I).

54. See Securities and Exchange Commission v. W. J. Howey Co., 327 U. S. 773 (r946) and Securities and Exchange Commission v. Joiner Corp., 320 U. S. 344 (I943), which involved a similar definition under the Securities Act of 1933, 48 STAT. 74 (I934), I5 U. S. C. $\$ 77$ (I940).

55. \&3 (I3).

56. \$3 (I4).

57. 6I F. Supp. 604 (S. D. N. Y. I945).

58. - F. (2d) - (C. C. A. 2d, I947). 
and the stockholder was not permitted to intervene in the district court. It is necessary for present purposes to discuss only the latter case where the defendants were trustees of a family trust which held a controlling interest in Park \& Tilford, Inc., including both preferred and common shares in that company. The corporation gave notice that the preferred stock ( $\$ 50$ par value) was to be redeemed by the corporation for $\$ 55.00$ per share. Shortly thereafter the defendants exercised their right to convert the preferred stock into common stock. This conversion took place when the stipulated market price of the common stock was approximately $\$ 58.25$ per share. That was in January, 1944. Beginning late in 1943 and ending in May, 1944, there was a spectacular rise in the market price of Park \& Tilford common stock "probably because of the rumor of an impending liquor dividend to be paid in liquor." 59 During this rising market, however, a substantial number of shares of common stock were sold by the defendant for prices as high as $\$ 98$ per share. Suit was instituted to recover the profits realized within six months.

The defendants resisted on the ground that their action was entirely involuntary, particularly because they were trustees, legally required under New York law to effect a conversion of securities where that conversion is beneficial to the estate, upon receipt of a notice of redemption. It was argued also that the definition of purchase did not include acquisitions on conversion of the securities. If any purchase took place, it was contended, the purchase was one which occurred more than six months prior to the sale, at the time the convertible preferred stock was acquired. Also urged was the claim that the common stock received on the conversion was "acquired in good faith in connection with a debt previously contracted" and hence within the exception expressed in Section I6 (b).

The court held, however, that defendants' election to convert as the more profitable alternative open to it did not make the transaction involuntary, that the definition of "purchase" in Section 3 (a) (I3) was intended to include all acquisitions and not merely the simple and conventional purchase transactions, and that the convertible stock could not be considered a previously contracted debt, nor its conversion into common as an acquisition of a security because of inability to obtain payment otherwise of the debt. The court ordered a judgment for the plaintiff issuer in a substantial amount. ${ }^{\text {co }}$

\section{Ibid.}

6o. The purchase price was considered the market value of the preferred on the conversion date, conceded by the parties to be $\$ 364,87 \mathrm{r}$. The market value of the common into which it was converted was $\$ 480,853.78$ on the same day. Since the proceeds from the sale of the common was $\$ 782,999.59$, damages were computed at $\$ 418,128.59$. 
Questions as to whether a purchase or sale is involved arise with respect to gifts, inheritances; redemptions, options, subscription rights, loans, pledges, charitable contributions, installment contracts, employee incentive plans, and bonus stock. These transactions also raise questions as to when the six months period starts, whether the purchase and sale are of securities of the same class and what criteria should be used in determining the purchase or sales price for the purpose of computing profits. Many of the specific cases are not entirely free from doubt. In general it seems clear that in determining whether the statute applies to the particular transaction, what dates should be taken, and what cost criteria should be chosen, the courts will resolve the question in the way which will best effectuate the express purpose of the statute to remove all incentive to insiders to profit from confidential information available only to them because of their position of trust.

A bona fide gift of securities would seem clearly outside the scope of the section, as would the usual charitable contribution. However, where the latter results in a substantial tax saving and is related to a purchase of the same or a similar quantum of the security it would be possible to conclude that a profit realized upon matching of the transactions is recoverable if the surrounding circumstances indicate that the transactions were susceptible to defeating the purpose of the statute. Loans and pledges would be treated as sales, we believe, only if under similar analysis they were found to be essentially a device to get around the Act. Significant in that connection would be the fact that the lender is to get a share of the profits from the transaction by the borrower.

Most of the problems that arise are with respect to options of one kind or another, including conversion rights. The option device lent itself quite readily to the abuses uncovered in the Congressional investigations antedating the Act. Moreover, the option warrant has been since the Act a prevalent method for compensating insiders and underwriters. The convertible security, including a convertible debenture, is specifically defined as an equity security, as is the conversion right, the subscription warrant and the stock option. In essence all of them are options to a lesser or greater extent.

The form which the right takes varies with the purposes underlying its issuance and the astuteness of counsel for the management or the bankers. The recent case of the Commissioner of Internal Revenue v. Smith ${ }^{61}$ which held that certain types of compensatory stock options

6r. 324 U. S. 177 (I945), rehearing denied, 324 U. S. 695 (1945). Petition for rehearing pending, respecting the basis used by the Court in determining the market value of the preferred. 
result in taxable income and the new Internal Revenue Regulation ${ }^{62}$ which goes even further toward making profits from options taxable income, have apparently resulted in the devising of various formulae intended to minimize the $\operatorname{tax}$ consequences to the recipient of the rights. However, the devices used create problems under Section 16 (b). For example, suppose warrants are issued to management not for compensation, but only as an incentive. Apart from the question as to whether it is in fact compensation, which for tax purposes appears to be largely settled in the affirmative by the new tax regulation, such options may be construed as acquisitions of equity securities, within the definition of "purchase" discussed above, so that a sale of such an option within six months might result in a realized profit under Section I6 (b). Similarly if there is a sale of a security of the same class as that underlying the option and within six months before or after such sale the option is exercised the latter might be considered an acquisition matchable against the sale under Section 16 (b).

While the statute does not specifically require that the matched transactions be of the same class, that seems to be the proper inference from the wording of the statute, particularly in the exemptive clauses, and also inferable from the practical difficulty of figuring profits if the classes are clearly different. ${ }^{63}$ However, whether the purchase and sale are of securities of the same class is not always determinable on a literal, narrow basis. The test should be whether the securities may be so assimilated as to afford a means of in-and-out trading profits derivable from use of inside information. For example, it is not unusual for an issuer to have two kinds of common stock outstanding, voting and non-voting. In view of their market relationship, trading in one and out of the other may be tantamount to a purchase and sale of the same security under Section I6 (b).

Suppose convertible preferred is sold and rights to buy common are acquired. It is arguable that both transactions involve rights and hence are securities of the same class. These transactions might also be considered, in some contexts, as in effect a sale and purchase of common. In the usual case the market for the convertible security would vary with that of the common in a fixed ratio and hence no great difficulty would be presented in computing short term profits derived from such transactions. A related case appears when stock is sold and matched by a purchase of warrants or subscription rights

62. INT. REV. REG. III, $\$ 29.22$ (9)-I (I943). The amendment is contained in T. D. 5507, April 12, 1946.

63. Smolowe v. Delendo, I36 F. (2d) 23I (C. C. A. 2d, I943), cert. denied, 320 U. S. 75 I (1943), cited note 53 supra. 
for the same stock. If the two transactions appear to be associated as part of a profit making device it is likely that a court will hold them to be of the same class for purposes of Section I6 (b). In reaching this conclusion we take notice, of course, of the argument that no profit actually accrues in this case prior to the exercise of the right.

Suppose (I) there is a sale of options and an acquisition of subscription rights covering the same class of stock; or (2) a sale of warrants matchable against an installment contract to purchase the stock. The transactions in both (I) and (2) in our opinion are so essentially the same as to be treated as the same class. A question whether the receipt of the option is to be considered a "purchase" is raised in the case of warrants or subscription rights issued periodically pursuant to a company-wide employees incentive plan. In order to avoid the reach of the Act it would have to be concluded that such an acquisition was not one which could be susceptible to short-swing abuses by insiders. Such plans are usually for the avowed purpose of increasing management's investment, rather than for speculation; hence the view that insiders should be permitted to utilize such rights to make a short-term profit would be contrary to the spirit of such a plan. A cognate case is involved in the issuance of bonus stock to a large number of employees under a fixed bonus plan. Unless riggable for the purposes of evading Section I6 (b) there would be practical arguments in favor of concluding that the acquisition of bonus stock under a general plan should not be treated as a "purchase" under the statute. In the case of rights received as a bonus or for incentive purposes the insider obtains greater leverage and control of the timing of the transactions and hence there is more likelihood of abuse. Where the bonus is not pursuant to an established bonus plan it would appear to be more amenable to use as an evasion device. Therefore, we believe that in such a case the acquisition of bonus stock would more likely be held to be a "purchase" matchable against any sale of that class of stock within six months. Furthermore, any sale of such bonus stock would be matchable for Section I6 (b) purposes against any purchase of the same class of stock within six months of such sale.

Whether a transaction is to be excepted as an acquisition in connection with an antecedent debt is essentially a question of fact as to the bona fides of the transaction. If it was not clearly necessary to take stock in payment, then we believe the courts will hold it not within the exception contained in Section I6 (b). If the debt were created under circumstances indicating that it was for the purposes of evading the statute, we believe the acquisition should be held not in "good faith." 
Suppose one transaction occurred before any equity security of the issuer was registered on an exchange. In our opinion if the last of the two transactions in question occurred after the registration of an equity security, then the profit would have been realized subject to the statute. A contrary ruling would permit realization of a profit from use of inside information with respect to a company which is within the class dealt with by the statute. A problem is also presented where the only security which has been registered is withdrawn from registration ${ }^{64}$ after one of the two transactions. A literal reading of the statute would indicate that this case is not within the statute which requires that the profit be realized from a purchase and sale of an equity security of an issuer which has an equity security registered on an exchange. However, it can be argued persuasively that the section should apply because the insider could have taken advantage of confidential information by effecting one transaction while the issuer was registered by $\dot{a}$ purchase or sale and effecting the matching transaction after delisting, all within six months.

An associated question arises when a director or officer is not such at the time of both the purchase and sale. The fact that the statute expressly requires a beneficial owner to be such at both times argues for the conclusion that it is not necessary for the director or officer to be such at both times. It seems clear that if he is a director at either time, he could have made use of inside information to obtain a profit for himself. The statute refers to profits realized by "him," meaning the insider. It is possible to argue that this language was intended to require that the director be such at the time of the transaction when the profit was realized. However, the word "him" as used in the statute may be construed as not necessarily signifying that he must be a director at the time when the profit was actually realized, but that it will suffice if he was such at the time when either of the transactions took place. This view is supported by the provision in Section 16 that the insider need not intend to reverse the transaction within six months.

Suppose the trading is done by a partnership or corporation of which a partner or controlling person is an insider with respect to the security bought and sold. In the partnership case it would seem that the partner-insider has a beneficial interest in the purchase and must report such ownership under Section 16 (a); and also must account for any profits from a sale thereof within six months. The problem of reporting the trading by a holding company in securities of an issuer of

64. Such withdrawal requires filing of an application with the Commission and compliance with terms imposed by the Commission in the interest of investors ( $\$$ I2(d), Rule X-I2D2-I). 
which a controlling person of the holding company is an officer or director is dealt with in a Commission Release. ${ }^{65}$ This rule may be briefly summed up by the statement that Section 16 (b) liability cannot be avoided by acting through what is in effect a holding company, the function of which is substantially to trade in behalf of said insider and those associated with him. It is of course a question of fact in each case as to the nature and purpose of the company. Special problems arising from distributing and underwriting transactions are dealt with in exemption rules adopted by the Commission. Because of their very specialized character we do no more at this point than refer the reader to Rule X-I6B-2 and X-I6C-2.

Fixing the time of the purchase or sale is important both to determine whether the short-term period was exceeded and to determine the prices to be used in computation of profits. In the case of an ordinary purchase through a broker, the time and price reported on the confirmation would ordinarily fix the rights of the parties and would seem the appropriate date for Section I6 (b) purposes. ${ }^{60}$

Suppose the purchase is on an installment contract binding on both parties, and the purchaser can obtain delivery of a portion or all of the stock at any time by making appropriate payment. Under this type of contract it is our view that absent special provisions impelling a different result, the contract date would start the six months period, both for later sales and those prior to the contract, and the purchase price would be that fixed in the contract.

A new type of installment contract has been evolved recently, presumably to avoid the latest treasury regulation governing options. The contract is a bifurcated affair. It contains provisions under which the purchaser has the right to make payments on account from time to time and to have equivalent shares set aside for him, delivery to be made only upon completion of all of the payments, and in the event of failure to complete the purchase, the payments made are to be retained by the company as liquidated damages. However, the larger payments are deferred to the latter part of the contract term, and the purchaser could escape any serious loss, if he decides not to complete the contract. As we analyze this type of installment contract it is similar in many respects to the acquisition of an option; however, in other respects it more closely resembles an acquisition of the underlying securities within the meaning of Section $16 .{ }^{67}$ The important question in-

65. Securities Exchange Act Release No. 1965 (I938). This release also discusses application of $\$ 16$ (a) to the partnership and related problems arising in trust situations.

66. Cf. Rule X-I5Cr-I.

67. As noted above, "purchase" by definition includes a contract to purchase or otherwise acquire and it has been held that this includes such executed acquisitions as conversions of preferred to common. See note 58 supra. 
volves fixing of the date when the acquisitions take place in order to determine whether other sales that may be matched with such acquisitions have resulted in a realized profit under Section I6. If the contract can be viewed as substantially the same as the grant of an option it would seem that it ought to be treated as such, and hence, the acquisition of the definitive security does not take place until the take-down. But assuming that the "contract" cannot be considered as an option because it is more like a "purchase," it is necessary to consider whether the date of acquisition should be the contract date or the date of actual delivery of the securities or any part thereof. In the case of a sale of the definitive security prior to the installment contract it appears to us that the contract date should be the significant date. Otherwise it would be a relatively simple matter to trade on inside information by selling from portfolio and effectually reacquiring the stock by obtaining such a "contract."

In respect to a sale of the definitive security subsequent to the subscription contract date we believe a court could justifiably hold that any sale within six months of either the contract date or any takedown date would come within the statute. Moreover, if several transactions are involved, such as a sale on November I, followed by purchase contract on January I, take-down on April I and sale on August I, we believe that the courts would compute the profits so as not to require the insider to pay to the issuer any sum greater than his actual profits attributable to the purchase contract and the aforesaid related transactions. Of course, each such case would have to be determined on the provisions of the particular contract, the relationship of the insider to the corporation, and the kind of trading carried on by the insider. If the nature of the installment contract was such as to present no likelihood of misuse to defeat the purposes of the statute, the court no doubt would construe an ambiguous contract in a way that would take the transaction thereunder outside of the statute.

A question arises when securities acquired by a partnership are distributed to the partners and they then sell. Is the date of acquisition the time when the firm buys or when the individual partner gets the security? The partner-insider would have to report the acquisition when the firm bought the security. That would ordinarily be the date when the six months period begins to run. However, if it appears that this technique is employed in a context indicating evasion of the statute, we believe the courts could construe it otherwise.

Calculation of the amount of the profits is relatively simple in the ordinary purchase and sale case. As in the tax field, expenses properly attributable to the transactions should be allowed, so that the 
prices used would be net to the insider. Problems of cost determination arise in option and conversion cases. Should the acquisition cost of the option warrant enter into the calculation? Suppose the warrant was received for past services or other valid consideration. We believe a court would allow such cost of the option if bona fide. If the options are only for incentive and definitely not compensatory it would seem no cost would be assigned to them in calculating profits.

The transferable option is itself an equity security subject to Section I6 (b), and profits from its acquisition and sale within six months inure to the corporation for there is often a going market for option warrants or similar rights. Nevertheless we do not believe that the value of the option can be considered in computing the profit realized from the exercise of the option and immediate sale of the stock. Since the option may be sold for approximately the difference between the exercise price and the market price of the stock, allowing this "worth" as part of the cost of the stock would leave no profit. Accepting the latter hypothesis would open a huge loophole in the section. However, the legislative history makes it clear that insider abuses effectuated through the option device was one of the very evils Congress sought to remedy. As the House Report emphasized: "The granting of options to pools and syndicates has been found to be at the bottom of most manipulative operations, because the granting of these options permits large-scale manipulations to be conducted with a minimum of financial risk to the manipulators." 68 In our view the provisions of Section I6 (b) and its legislative history will support a determination that the "value" of the option (that is to say the difference between the market price of the security and the exercise price) will not be allowed in the computation of Section I6 (b) profits. A contrary holding, in our opinion, would defeat the remedial purposes of the statute.

In our opinion short-term profit from an acquisition of an option and disposition of it by exercise is not recoverable under Section I6 (b) absent other transactions. The disposition (by exercise) in the ordinary case would not be a sale of the option, since the option is not the consideration for the security received; the option is merely a token of the privilege to choose the time of purchase. To be sure, the exercise of the option is a purchase of the security received, at the exercise price, but if that purchase is not matchable against a sale within six months thereof, there would appear to be no profit under Section $\mathrm{I} 6$ (b). We would take a contrary position if instead of exercising the

68. H. R. REP. I383, 73d Cong., 2d Sess. (I934) I0-II ; see also SEN. REP. I435, 73d Cong., 2d Sess. (I934) 55-63. Compare Rule X-I6B-3, which reflects the Commission's view that exercise of options would result in $\$ 16(\mathrm{~b})$ liability. 
option, it is sold within six months in the open market at a profit or exchanged with the issuer for a more favorable option. In the Park \& Tilford case ${ }^{69}$ which involved the conversion of preferred stock into common, the court held that "Under' the statute the amount recoverable by plaintiff is the receipts from the sale of the stock, minus the purchase price. The common stock in question here was purchased by exchanging preferred for it. Its purchase price was therefore the market value of the preferred on the conversion date."

The convertible security is obviously composed of a security plus an option. Whether the convertible security is to be considered on the same or a similar basis as an option for profit computation purposes depends on its essential characteristics. If it is basically an option its value should not be included in the cost of the security received, except to the extent that any material value can be assigned to the security converted. On the contrary, if it is inherently a security, the option to convert being only incidental thereto, the market value of the convertible security would probably be held to be the exchange equivalent for the security received on conversion.

\section{Rule Making Power and Constitutionality}

\section{(a) Rule Making Power}

Administrative rules may be roughly classified as procedural or substantive. ${ }^{70}$ Although the Commission has found it necessary to adopt a complete set of rules of practice to govern actions commenced before it as an administrative tribunal, these rules generally have no effect upon Section I6, for that section is enforceable only in the district courts of the United States. ${ }^{\text {on }}$ Substantive rules, adopted under the Act, pursuant to. Sections 3 (b), I6 (b), I6 (d), and 23 (a) of the Act, however, are applicable to Section I6. Section 3 (b) provides that the Commission may "define technical, trade, and accounting terms used" in the Act so long as they are not inconsistent with any of its provisions. This permits the Commission to cast its interpretation of the statute into the form of definitions of the words used. Under it, the Commission has defined such words as "listed," 71 "officer," 72 and "short sale." 73

69. Discussed supra at p. 483 .

70. Another classification, interpretative rules, may more properly be considered substantive. See Blair-Smith, Forms of Administrative Interpretation Under the Sectrities Lazes (I94I) 26 IowA L. REv. 24I.

70a. Confidential treatment of $\$ I 6$ (a) filings are, however, affected by S.E.C. Rule of Practice XIII.

7I. Rule X-3B-I.

72. Rule $\mathrm{X}-3 \mathrm{~B}-2$.

73. Rule $\mathrm{X}-3 \mathrm{~B}-3$. 
Section I6 (b) grants to the Commission the right to exempt from that subsection any transactions which may not be comprehended within its purpose. This is very plainly a power to regulate substantive rights. However, it is limited by the requirement that no exemption be granted unless it conforms to the purpose of Congress as expressed in the Act. Accordingly, the power has been utilized sparingly. Thus far, the rule-making power granted by this subsection has been utilized to exempt transactions in certain enumerated types of securities, transactions originated prior to October I, 1934 , or in the case of employee options, prior to June 6, I934, transactions by public utility holding companies and their subsidiaries, and certain distributing and underwriting transactions. ${ }^{73 a}$ The Commission concluded that these transactions were not within the intent of Congress, and so it was deemed desirable to exempt them from the liability imposed by Section 16 (b).

Section I6 (d) broadly delegates to the Commission the power to make "such rules and regulations as the Commission may adopt in order to carry out the purposes of this Section." It is a corollary to the Section I6 (b) rule making authority. Both grants of power are restricted by the purposes of the section, which are defined generally in Section 2 and more specifically in the first clause of Section I6 (b). Taken together, they delegate to the Commission the power to exempt transactions not comprehended with the purposes of the Congress and to adopt whatever rules are necessary to assure that all transactions properly within the area prescribed by Congress are subjected to the liabilities of the Section. ${ }^{74}$

Finally, Section 23 (a) grants to the Commission the "power to make such rules and regulations as may be necessary for the execution of the functions vested in [the Commission] by this title." This has no specific reference to Section I6 of the Act, but applies to all of the provisions of the Act, and delegates a broad power to issue any rule or regulation the Commission deems necessary to protect the interests of investors.

Considerable latitude is provided by these sections for the exercise of administrative discretion. In a field as technical as that covered by the Securities Exchange Act a broad discretion is essential if the Act

73a. See Rules X-12F-4, X-16B-I, X-16B-3, X-16B-4 and X-16B-2. Under this last Rule, underwriters affiliated in any way with the issuer are exempted from the liability imposed by $\S 16$ only if other persons, who are not affiliated with the issuer, "participate in the purchase . . . on terms at least as favorable as those" of the affiliated underwriter "and to an extent at least equal to the aggregate participation" of the affiliated underwriter. See also Rule X-16C-2 with respect to short sales.

74. The only rule thus far adopted under $\$ 16$ (d) is Rule X-I6D-I, which makes it unlawful for any officer or director of an issuer of an equity security registered on an exchange to engage in an arbitrage in any equity security of that issuer, whether registered or not and renders any such arbitrage subject to $\$ \S I 6(a)$, I6 (b) of the Act. 
is to be workable. It would be impossible to "define the whole gamut of remedies... . in an infinite variety of situations. Congress met these difficulties by leaving the adoption of means to end to the empiric process of administration." 75 The rules promulgated pursuant to the statutory mandate are then enforced by the courts as if they were a part of the statute itself. ${ }^{\text {?6 }}$

\section{(b) Constitutionality}

The Securities Exchange Act was passed to cure evils disclosed in an extensive investigation of stock exchange practices conducted by the Senate Committee on Banking and Currency of the 73rd Congress. The record of this investigation and the report of the Committee are replete with instances of the misuse of information by corporate insiders for their personal profit in security transactions. The reports of the Senate and House Committees which considered the proposed legislation demonstrate, by their frequent reference to such misuse of inside information, the part which abuse of corporate position played in preventing honest markets and in destroying investor confidence in the stock markets and in the companies whose securities were traded on such exchanges.

As a result of the investigation Congress made a finding, which it incorporated in Section 2 of the Act, that it was necessary in the public interest to regulate and control not only stock exchanges and transactions in securities commonly conducted upon such exchanges but also practices and matters related thereto, "including transactions by officers, directors, and principal security holders." Section I6 (b) is one of the measures adopted by the Act to effectuate this regulation and control.

It is no longer open to question either that stock exchanges are proper subjects for federal regulation ${ }^{77}$ or that Congress may impose whatever requirements it deems in the public interest to regulate practices in connection with such subjects. ${ }^{78}$ The constitutionality of Section I6 (b) has been attacked chiefly on the ground that its specific provisions do not provide the safeguards necessary to a proper exercise of the Congressional power. It is contended that the insider, by being compelled to disgorge his profits regardless of whether it can

75. Phelps Dodge Corp. v. Labor Board, 313 U. S. I77, I94 (I94I).

76. Arent v. United States, 266 U. S. I27 (I924); cf. Manhattan G. E. Co. v. Commissioner, 297 U. S. 127 (1936). I (I923).

77. Currin v. Wallace, 306 U. S. I (I939); Board of Trade v. Olsen, 262 U. S.

78. American Sumatra Tobacco Corp. v. Securities and Exchange Commission, IIo F. (2d) II7 (App. D. C. I940); Wright v. Securities and Exchange Commission, II2 F. (2d) 89 (C. C. A. 2d, I940); R. J. Koeppe \& Co. v. Securities and Exchange Commission, 95 F. (2d) 550 (C. C. A. 7 th, 1938). 
be proved he took unfair advantage of his position, is deprived of his property without due process of law; and that the statute improperly delegates legislative authority to the Commission.

In the cases which have ruled on these questions ${ }^{79}$ both contentions were rejected. In the leading case on the subject, Smolowe v. Delendo Corp., involved a suit by stockholders of the Delendo Corporation against persons who were officers, directors, and 12 percent stockholders in the corporation to recover the profits they made as a result of trading in Delendo Corporation securities during a time when negotiations were in progress for the sale of the corporation's assets.

In holding Section I6 (b) constitutional the Court indicated that the rule of thumb providing for the recapture of profits did not infringe the due process guarantees. It was the tendency to evil which the statute was designed to overcome, and in doing so the Act would necessarily catch bona fide transactions. This, however, did not render the provision unconstitutional. Although the Court did not feel compelled to rule upon the constitutionality of the delegation of authority to the Commission to grant exemptions because no regulation injurious to the defendants had been promulgated by the Commission it indicated that an adequate standard had in fact been prescribed to guide the Commission. ${ }^{80}$

Another argument which may be met is that, assuming Section I6 (b) is constitutional as applied to directors or officers of a corporation the same reasoning would not apply to holders of a ten percent interest because the latter do not have access to the secret information the threat of misuse of which furnished the basis for the statute. However, as a result of its investigation Congress found that principal security holders, as well as officers and directors, had access to and misused information which came to their attention by virtue of their control over the corporation, and incorporated this finding in Section 2 of the Act. It is reasonable to suppose that management would be responsive to a principal stock interest, and would take no important action without consulting it. Accordingly, such a stock interest bears a responsibility at least equal to that of management. ${ }^{\text {s1 }}$

Facilitation of administration makes it reasonable to set a specific quantum of ownership which will include the great majority of those who dominate a corporation without at the same time reaching those

79. Park \& Tilford, Inc. v. Schuite, - F. (2d) - (C. C. A. 2d, I947) ; Smolowe v. Delendo Corp., I36 F. (2d) 231 (C. C. A. 2d, I943); Kogan v. Schulte, 6r F. (2d) 604 (S. D. N. Y. I945).

So. Smolowe v. Delendo Corp., I36 F. (2d) 23I, 240 (C. C. A. 2d, 1943).

8I. See Park \& Tilford, Inc. v. Schulte, cited supra note 58; Southern Pacific Co. v. Bogert, 250 U. S. 483 (I9I9), in which majority stockholders were held fiduciaries for the minority. 
who would be apt to have practically no share in management or in access to inside information. In the first bill introduced, this figure was set at five percent. ${ }^{82}$ It was revised upward until, as finally enacted, the Act required a ten percent interest. Ownership of ten percent of any class of equity security, Congress found, vested sufficient control of a publicly held corporation in a person to permit him to participate with management in the direction of the enterprise and to receive news of all important actions contemplated by the corporation. This finding is sufficient to support the reasonableness of the criterion so long as the activity regulated or prohibited is within the reach of the federal power, and it appears clear that it is. ${ }^{83}$ It is unnecessary that there be a judicial finding on the subject. ${ }^{84}$

\section{UnRegistered Securities}

Thus far we have considered trading which for the most part takes place on securities exchanges, for Section $I 6$ is restricted to securities of issuers which have an equity security "registered on a national securities exchange." ${ }^{85}$ A much larger area for the unfair use of information obtained by reason of the relationship between the insider and the corporation exists in the large number of organizations whose securities are traded on the over-the-counter market. Some corporate. managers prefer not to have the corporation's securities listed on an exchange in order to avoid the limitations on and the publicity attending insider trading. ${ }^{86}$ In one case the corporate insiders, while they were seeking permission from the Commission to delist, were engaged in the purchase at 90 of the 7 percent preferred stock of their company which had a call price of $\mathrm{I} 2 \mathrm{O}$, and shortly after the delisting was effected the company actually called the stock. ${ }^{87}$

Although the rule of thumb which imposes upon insiders who trade in registered securities an absolute liability for the profits made as a result of purchases and sales within six months of each other is inapplicable to transactions in securities of issuers which do not have an equity security listed on an exchange, a liability in addition to that

82. S. 2693, 73d Cong., 2d Sess. (1934) ; H. R. 7852, 73d Cong., ad Sess. (1934).

83. United States v. Darby, 3I2 U. S. roo, I20-I2I (I94I).

84. The American Power and Light Company v. Securities and Exchange Commission, 67 U. S. 133 (I946); U. S. v. Carolene Products Co., 304 U. S. I44 (I938); South Carolina Highway Department v. Barnwell Bros., 303 U. S. I77 (I938).

85. \$ 16 (a). Of course, trading in any equity security of such an issuer, whether on the exchange or not and whether the security traded in is registered, is subject to $\S \mathrm{I} 6$, and most of such trading takes place on exchanges.

86. In the Matter of Joslyn Manufacturing and Supply Co., Io S. E. C. Decisions AND RePoRTS 3II (Dec., I94I).

87. Rudolph Wurlitzer Co., Securities Exchange Act Release No. 33I5 (1942). 
imposed by the common law may exist by virtue of Section Io (b) and 29 (b) of the Securities Exchange Act. ${ }^{88}$

Section Io (b) makes it unlawful "to use or employ, in connection with the purchase or sale of any security registered on a national securities exchange, or any security not so registered, any manipulative or deceptive device or contrivance in contravention of such rules and regulations as the Commission may prescribe as necessary or appropriate in the public interest or for the protection of investors." 89

Pursuant to the authority granted by this section the Commission in 1942 promulgated a rule, numbered X-roB-5, which makes it unlawful by use of the federal facilities (I) to engage in any device, scheme, or artifice to defraud, or (2) make any untrue statement of a material fact or omission to state a material fact, or (3) perform any act, practice, or course of business which operates as a fraud or deceit upon any person, in connection with any purchase or sale of any security. Although an insider may not be liable for profits which result from all transactions in his corporation's securities, it is probable that such purchases made on the basis of material inside information not made available to stockholders will be held in violation of the abovementioned rule by reason of his failure to disclose. In view of the strongly indicated legislative intent to reach abuses of insider position ${ }^{80}$ it seems reasonable to forecast that the courts will construe the rule to effectuate that purpose. However, the difficulties in such a case would be underscored when the trading is done on an organized exchange, because it is impersonal in character, and it may be impossible to establish privity.

These unlawful acts may be the subject of either injunctive action at the suit of the Commission ${ }^{91}$ or criminal action. ${ }^{92}$ Recently, it has been held that there is also a private right of action to recover damage deriving from a violation of Rule X-IoB- 5 on the theory that members of a class for whose protection a statutory duty is created may sue for injuries resulting from its breach. ${ }^{93}$ This doctrine has been firmly

88. Of course, $\S \S$ Io (b) and 29 (b) apply also to transactions subject to $\$$ I6 liabilities. Fry v. American Cone and Pretzel Co., - F. Supp. - (E. D. Pa. r947).

89. 48 Stat. 89I (1934), I5 U. S. C. A. $\$ 78 j$ (b).

90. See H. R. REP. I383, 73rd Cong., 2d Sess. (I934), where it was said: "The causes of dangerous speculation in the securities markets. . . include exploitation of [investor] . . ignorance by self-perpetuating management in possession of inside information."

9I. $\S 2$ I (e).

92. $\$ 2 \mathrm{I}(\mathrm{e})$ and $32(\mathrm{a})$.

93. Kardon v. National Gypsum Co., - F. Supp. - (E. D. Pa. I946) ; FifthThird Union Trust Co. v. Bloch, Civil Action No. I507 (Unreported, S. D. Ohio I946) ; Slavin v. Germantown Fire Ins. Co., Civil Action No. 6564 (Unreported, E. D. Pa. I946). For a contrary view see Note, SEC Action Against Frandulent Purchasers of Securities (I946) 59 HARv. L. REv. 769. 
established in the federal courts, whether the statute involved is an enactment of the state legislature or of the federal Congress. ${ }^{94}$ However, the essential question in each case is the intent of the legislature to confer or withhold such relief. Ordinarily intent to give such a remedy will be found unless there is clear indication to the contrary. In fact, it has been applied to an action instituted by certain investors against the New York Stock Exchange for damages resulting from the failure of the exchange to enforce a rule adopted pursuant to Section 6 (b) of the Securities Exchange Act. ${ }^{95}$

Section 29 (b) of the Securities Exchange Act, which invalidates contracts made in violation of the Act, would also furnish the basis for such an action in cases where a contract is involved performance of which or the making of which involves a violation of the Act. Under Section 29 (b) suit might properly lie for rescission, or if that remedy is unavailable, for such other relief as will prevent the defendant from profiting from his unlawful act. ${ }^{96}$

\section{Effects of Section 16}

There has been no significant disagreement with the underlying purpose of Section I6 since the Act was passed. ${ }^{97}$ The Act itself was the culmination of a long series of investigations by governmental and private committees and was aimed at correcting the abuses which those investigations disclosed, among which trading by insiders in order to take unfair advantage of information possessed by them in their official capacity loomed large. ${ }^{98}$ While concededly the prophylaxis prescribed by Congress to remedy these abuses was not expected to completely banish them, we think that it has been reasonably effective in achieving its purpose. In twelve years the Commission has had to resort to the courts in only one case to enforce the reporting requirements of Section 16 (a) ${ }^{99}$ and there have been only a handful of private suits to recover Section I6 (b) liabilities. In a relatively

94. Texas \& Pacific Ry. Co. v. Rigsby, 24I U. S. 33, 3940 (IgI6) ; Zajkowaski v. American Steel \& Wire Co., 258 Fed. 9 (C. C. A. 6th, I9I8); Armour v. Wanamaker, 202 Fed. 423 (C. C A. 3d, I9r3) ; Narramore v. Cleveland C. C. \& St. L. Ry. Co., 96 Fed. 298, 300-30I (C. C. A. 6th, I899); Donaldson v. Tuscon Gas, Electric Iight \& Power Co., I4 F. Supp, 246, 247-248 (D. Ariz. I935); see also Abonnader v. Strohmeyer \& Arpe Co., 243 N. Y. 458, I54 N. E. 309 (I926).

737 (1944).

95. Baird v. Franklin, I4I F. (2d) 238 (C. C. A. 2d, I944), cert. denied, 323 U. S.

96. Cf. Deckert v. Independence Shares Corp., 3II U. S. 282 (I940).

97. See Hearings Before the Commitiee on Interstate and Foreign Commerce on H. R. $4344, H$. R. $5065, H$. R. 5832,77 th Cong., Ist Sess. (I94I) I247.

98. For a brief history of stock market regulation in this country see Tracy and MacChesney, The Securities Exchange Act of I934 (I934) 32 MICH. L. REv. 1025, I033-1036.

99. Securities and Exchange Commission v. I. A. Young, Civil Action No. 4I54 (E. D. Mich. I945). 
small number of instances the Commission has found it necessary to require disclosures in proxy statements, registration statements and annual reports of information respecting short-term trading by management. ${ }^{100}$ Not infrequently when indicated liability under Section 16 (b) is called to the attention of the insider payment has been made to the issuer, possibly because insiders prefer to pay rather than disclose their trading profits directly to the stockholders. We understand the volume of trading by executives of public utility holding companies and railroad companies in the securities of these companies has been small, probably because they are more sophisticated than management generally in terms of regulatory statutes. ${ }^{101}$ Moreover, the management of public utility companies faces the possibility of being limited to cost plus interest in any trading conducted by them during the pendency of reorganization procedures, pursuant to Section II of the Public Utility Holding Company Act. ${ }^{102}$

Probably there has been a substantial amount of trading in securities of other companies on the basis of information given them by their opposite numbers in those companies, and vice versa. Although we assume that a certain amount of this corporate log-rolling is inevitable, the incentives are not nearly as great and difficulties inherent in the process will tend to make it much less a source of abuse, than if the door were wide open to speculation by corporation executives in securities of the corporation. Trading through friends or relatives involves, of course, the risk of Section 16 (b) suits which together with the lesser incentives involved in trading through others are limiting factors on such trading. On the whole we think it fair to assume that the legislative prescription has substantially accomplished the results intended, viz., to curb speculation by insiders on the basis of corporate information which, as a prominent stock exchange representative once stated in his testimony, they would be less than human not to be sorely tempted to do. ${ }^{103}$

I0o. The proxy rules require disclosure in proxy statements of stipulated information respecting the indebtedness of certain officers, directors who served the previous year, and directors listed for election. Section I6 (b) liabilities are includable in this item. The Commission merely requires a statement of the facts and the possibility of liability, and permits statements that in the opinion of the management there is no liability. Schedule I4A, Item 5 (I) (4). In certain cases disclosures as to options, bonus securities, etc., becomes pertinent to registration statements filed in connection with security offerings (Form S-I) under the Securities Act of I933, and also in some instances such information is pertinent to annual reports (Form Io-K) filed pursuant to the Securities Exchange Act of I934.

IOI. It is to be noted that the Holding Company Act $(\$ I 7)$ does not include $10 \%$ beneficial owners, but only directors, and officers, in the class which must report, and are subject to liability in respect of, their trading in company securities. For comparison with the coverage of $\$ 30$ (f) of the Inwestment Company Act see Securities Exchange Act Release No. 2687 (1940).

102. S.E. C. v. Chenery Corporation, 3I8 U. S. 80 (I943). A second appeal is awaiting decision in the Supreme Court.

I03. See note 97 supra. 
Any discussion of the merits of Section I6 (b) must be in the frame of reference of this basic human factor. Trading by management, considered unobjectionable in the smaller family type corporations, was carried over into the large publicly owned companies. Such activities by management create a duality of interest in the corporate executive which has been recognized by all as an evil which must be eradicated. It is this conflict of interest, the pull of contending influences and temptations which make speculative insider trading inherently.wrong. It is horn-book law that a fiduciary cannot serve two. masters. Accordingly, in considering the arguments against the statute which have been advanced by the securities industry it is important to keep in mind that the activities constrained-however beneficial they might or might not be in respect to the securities markets-contravene basic equitable principles, uniformly and rigidly enforced by courts of chancery. ${ }^{104}$

Suggestions for the amendment of Section I6 have heretofore been made by representatives of the securities industry, ${ }^{105}$ who are understandably interested in greater trading for the commissions and profits involved. The stock exchanges, brokers and investment bankers have sought to extend the provisions of Section I6 (a) and Section I6 (c) to include many of the large corporations now exempt from those requirements. ${ }^{106}$ However, in the past they have indicated a desire to restrict the application of Section 16 (b), or to repeal it outright.

An argument advanced against Section I6 (b) is that the Act is not a completely effective deterrent to insider speculation. That is conceded. But we believe it does go a long way toward remedying the worst aspects of the practice. Although considerable trading in their own corporations' securities is still done by insiders the dearth of claims under Section I6 (b) indicates that relatively little of this is for the purpose of short swing speculative profits, particularly in view of the comparatively simple process for recovery of such profits. Indeed, even if it be assumed arguendo that there is considerable evasion, that would not justify removing the restraints imposed by Congress, any more than it would be proper to repeal the anti-smuggling laws, if there were indications of widespread cvasions or violations of such laws.

I04. Woods v. City National Bank and Trust Co., 3r2 U. S. 262, 268-9 (I94I); American United Mutual Life Insurance Co. v. City of Avon Park, 3II U. S. I38, I47 (1940); Meinhard v. Salmon, 249 N. Y. 458, I64 N. E. 545 (I928).

105. See note 97 supra.

I06. A similar proposal was made by the Commission in a report to Congress entitled: A Proposal to Safeguard Investors in Unregistered Securities (1946), which was introduced near the end of the 79th Cong. as $\mathrm{H}$. R. 7I5I. 
Nor does it appear that publicity alone would be an adequate deterrent to such short-swing profits. The reports filed under Section I6 (a) receive only limited publicity, and often public dissemination of their contents is delayed.107

Let us assume that the publicity provisions of Section $x 6$ are broadened to an extent which would assure that the proper information is brought home to the individual stockholders. It is nevertheless difficult to see how the individual stockholder can effectively correlate information as to trading with developments in the affairs of the corporation in order to ferret out misuse of inside information. In view of the practical difficulties both with respect to getting the necessary data and in doing anything about it which would constitute a real threat to management, it is dubious indeed whether the remote possibility thereof would amount to much of a deterrent to management. Any assertion of impropriety is easily denied by the strongly entrenched insider. Moreover, proxy fights are expensive and rarely successful. Past experience, too, indicates that publicity alone is an ineffective sanction, for the disclosure provisions of the Securities Act of 1933 and the Securities Exchange Act of 1934 were not enough to stop the malpractices in the investment field. Congress was finally compelled to meet this problem by regulatory legislation, enacting the Investment Company Act of 1940. ${ }^{10 \mathrm{~S}}$

It has been contended also that speculative trading by insiders is desirable because it retards undue declines and rises in the market and otherwise broadens the market. This argument appears to be inconsistent with the claim that the statute has not had the intended deterrent effect. Moreover, that such a stabilizing effect results from insider trading is doubtful. The volume of such trading, although involving a substantial number of shares, is relatively insignificant in view of the exceedingly small percentage of the total volume which such trading represents, we are informed. Moreover, evidence is lacking that management would to any substantial degree unselfishly commit large amounts of personal funds to bolster the market because of their desire to benefit the company or its public stockholders. This

107. The reports are filed within Io days after the close of the calendar month in which the trading occurred. Then, time is required to compile and publicize their contents. The stock exchanges have taken steps to release this information through the broad tape as promptly as possible.

108. 54 Stat. 789 (1940), I5 U. S. C. \$80a-I et seq. The report of the House Committee on this bill itself stated:

"The Securities Act of I933 and the Securities Exchange Act of 1934 have not acted as deterrents to the continuous occurrence of abuses in the organization and operation of investment companies. Generally, these acts provide only for publicity. The record is clear that publicity alone is insufficient to eliminate malpractices in investment companies." H. R. REP. 2639, 76th Cong., 3d Sess. (I940) 244 . 
is consonant with management's position; its function is to manage the company, not the stock market.

It seems to us that there are powerful economic forces which determine the breadth of the market and that the huge number of shares outstanding in the case of the large-publicly owned companies, in which management usually has a very small personal stock interest, makes it highly improbable that trading by management will have a significant effect in preventing attenuation of the market. Moreover, the fundamental vice in encouraging speculative trading by management as a bolster to the securities markets is the resultant creation of inevitable and pervasive conflicts of interest which contravene basic principles of law and ethics.

It is no answer to assert that management generally will not trade on inside information. As was so realistically and candidly conceded by the representative of industry in the hearings in connection with a bill to amend the Securities Exchange Act, an insider would be less than human were he not tempted by such information, and it is just such temptations that the law in the same or similar contexts has rigidly guarded against. The Supreme Court recently reiterated in Woods v. City National Bank and Trust Company ${ }^{109}$ that it is the subtle play of conflicting forces, unprovable for the most part in a specific case, ${ }^{110}$ which is guarded against by the strictly applied equitable doctrine that the trustee shall not be permitted to use his strategic position to profit himself.

In any event, Section 16 (b) does not prevent selfless support of the market; all it says is that profits on short-swings shall inure to the company. Finally, we are aware of no instance in which it has been demonstrated that an insider failed to purchase or sell securities to cushion a fall or stop a rise in the market because of the responsibility he might incur under Section I6 (b). ${ }^{111}$ Moreover, transac-

I09. 312 U. S. 262, 268 (I94I). The court aptly stated: "The principle enunciated by Chief Justice Taft in a case involving a contract to split fees in violation of the bankruptcy rules, is apposite here: 'What is struck at in the refusal to enforce contracts of this kind is not only actual evil results but their tendency to evil in other cases.' Weil v. Neary, 278 U. S. I60, 173. Furthermore, the incidence of a particular conflict of interest can seldom be measured with any degree of certainty. The bankruptcy court need not speculate as to whether the result of the conflict was to delay action where speed was essential, to close the record of past transactions where publicity and investigation were needed, to compromise claims by inattention where vigilant assertion was necessary, or otherwise to dilute the undivided loyalty owed to those whom the claimant purported to represent. Where an actual confict of interest exists, no more need be shown in this type of case to support a denial of compensation."

Iro. This view of the need for deterrents not dependent on proving a subjective state of mind is also underscored by the action of Congress in 1938 in enacting $\$ 249$ of the BANRRUPTCY ACT. See In re Midland United Company, $-\mathrm{F}$. (2d) - (C. C. A. 3d, I947).

III. In the only specific instance called to the attention of the Commission of an insider who refrained from supporting the market in his corporation's securities because 
tions by insiders would frequently involve a period of time in excess of six months and could be undertaken without running afoul of Section 16 (b).

It is also claimed that Section I6 (b) contains an unfair implication that all insiders are dishonest. At the very least, it is contended, the section should be amended so that only insiders who cannot prove the validity of their motives should be liable for short-swing profits. Of course, such an amendment would lead to protracted and difficult litigation aimed at determining a state of mind at a particular time. It would, moreover, create an obstacle to recovery which in the usual case would be insurmountable because of the limited resources of individual security holders. As the Supreme Court said in Securities and Exchange Commission v. Chenery Corp., et al.: "Abuse of corporate position, influence, and access to information may raise questions so subtle that the law may deal with them effectively only by prohibitions unconcerned with the fairness of a particular transaction." 112 A striking analogy is the Banking Act of I933, to which no dissenting voice has been raised, which provides in general that a banker should not engage in underwriting securities because his interest in the success of the underwriting would frequently conflict with his fiduciary obligation to trust funds in his care and with his moral obligations to depositors. ${ }^{113}$

Accordingly, both common law and statutory law have imposed upon fiduciaries an absolute obligation to refrain from representing conflicting interests or to engage in any activity which creates conflicting pressures. Obviously this cannot be considered an imputation of dishonesty to all fiduciaries. No one would contend that the Banking Act of 1933 impugns the honesty of bankers or that Section 249 of the Bankruptcy Act does the same with respect to all trustees, protective committees, etc., in corporate reorganization.

That Section 16 (b) is sound legislation was attested by one of the leading representatives of the public utility industry of this country in advocating the extension of all of Section 16 to public utility holding companies at the time of the hearings on the Public Utility Holding Company bill. Mr. Wendell Willkie then said:

of the possible effect of his actions upon his $\$ \mathrm{I} 6$ (b) liability it developed that the insider refused to make any purchases long after any possibility of such liability was removed and after the price of the stock had dropped still further. Hearings, supra note I03, at pp. 1258-1259.

II2. 318 U. S. 80, 92 (I943).

Ir3. See Board of Governors of the Federal Reserve System v. Agnew, 67 S. Ct. 4II (I947), in which the Supreme Court said: "Section 32 [of the Banking Act of I933] is directed to the probability or likelihood, based on the experience of the I920's that a bank director interested in the underwriting business may use his influence in the bank to involve it or its customers in securities which his underwriting house has in its portfolio or has committed itself to take." 
"There is no question that the provision you gentlemen made about officers not using inside information for personal profit was a salutary measure, and was merely a reaffirmation of the trust obligation which men should have obeyed anyhow." 114

II4. Hearings Before the Senate Committee on Interstate Commerce on Sen. I725, 74th Cong., Ist Sess. (I935) 600. 